\title{
The Genesis of Kashmir Dispute
}

\author{
Hau Khan Sum ${ }^{1}$, Ravichandran Moorthy ${ }^{2} \&$ Guido Benny $^{3}$ \\ ${ }^{1}$ Ministry of Foreign Affairs, Myanmar \\ ${ }^{2}$ School of History, Politics and Strategy, Faculty of Social Sciences \& Humanities, University Kebangsaan \\ Malaysia, Bangi, Malaysia \\ ${ }^{3}$ Institute of Malaysian and International Studies, Universiti Kebangsaan Malaysia, Bangi, Malaysia \\ Correspondence: Ravichandran Moorthy, School of History, Politics and Strategy, Faculty of Social Sciences \& \\ Humanities, University Kebangsaan Malaysia, UKM Bangi, Selangor 43600, Malaysia. Tel: 603-8921-3266. \\ E-mail: drravi5774@gmail.com
}

\author{
Received: April 3, 2013 Accepted: June 20, 2013 Online Published: August 30, 2013 \\ doi:10.5539/ass.v9n11p155 \\ URL: http://dx.doi.org/10.5539/ass.v9n11p155
}

\begin{abstract}
In Indo-Pakistan relations, conflict, rivalry and hostility started immediately after their independence in 1947 followed by the first Indo-Pakistan war. Their bilateral relations have always been jeopardized by the Kashmir issue. They fought three conventional wars and faced several crises during the pre-nuclear and nuclear periods over the question of Kashmir. Both states attempted to acquire nuclear weapons with the primary aims of balancing each other and deterring wars. As a result, the possession of nuclear weapons by India and Pakistan have in turn generated arms races, crises, rivalries and increased their hostile relations. Both countries have been trying to find mutually acceptable solution to the question of Kashmir issue since the time of its inception. In addition to the third party interventions, a number of bilateral negotiations at different levels have been initiated by the two countries to settle the protracted issue. This article provides critical examination on the genesis of this conflict. The article is divided into sections discussing the Hindu-Muslin antagonism, the formation of the Jammu-Kashmir state, the partition of 1948, accession of Kashmir to India and the UN intervention into this territorial dispute. The article employs a qualitative research methodology, primarily relying on the analysis of printed and written materials such as books, academic journals, magazines and newspapers. The primary findings suggest that the failure of bilateral negotiations has protracted the conflict and has contributed to the deepening of mistrust between these two nuclear countries.
\end{abstract}

Keywords: Jammu-Kashmir, Indo-Pakistan relations, territorial dispute, war

\section{Introduction}

Jammu and Kashmir was one of the princely states throughout the Indian subcontinent. Although the majority of its population was Muslim, the ruler was Hindu. In 1947, Maharaja Hari Singh, the princely ruler, was allowed to join either of the two newly independent countries - India or Pakistan. At first, he was hesitant to join India (Tremblay, 2009). He delayed making a decision until Britain's departure from the subcontinent. But at a time when the Pathen tribesmen from Pakistan's north western regions invaded Kashmir, he was unable to prevent his princely state from this alien invasion and therefore he finally requested Indian Government to render necessary military support (Ganguly \& Kapur, 2010).

India first made sure that until and unless the princely state formally accedes to the state to India, it would be impossible to provide any military assistance. Under this condition, Maharaja Hari Singh signed the Instrument of Accession on $26^{\text {th }}$ October 1947 (Tremblay, 2009).Accordingly, India provided its military assistance on the next day and was able to retake two-third of the princely Jammu and Kashmir state from the invasion of the Pakistani tribesmen. However, the remaining portion went under the control of Pakistan. Meanwhile, India brought the issue to the United Nations (UN). Accordingly, the UN intervened to the issue and the two countries agreed to ceasefire on $1^{\text {st }}$ January 1949.

In addition to the resolutions and mediation of the UN to hold a plebiscite, a series of bilateral talks and peace process have been conducted by India and Pakistan to settle the Kashmir dispute. However, the two countries could not achieve solution as none of them is ready to revise their positions. India maintains that those portions of Jammu and Kashmir that are already part of India cannot be segregated from the Republic of India. In other 
words, India refuses to budge from its fundamental stand that the accession of Kashmir is final and non-negotiable (Dixit, 2002). Similarly, Pakistan also views that its claim to Kashmir is firmly based on the two-nation theory; it is unfinished agenda of the partition of the sub-continent whose final status must be determined by the people of Kashmir through plebiscite (Dixit, 2002). As a result, there has been little forward movement on the path to the settlement of Kashmir issue.

The difficulty in achieving solution to Kashmir issue has further been exacerbated by the development of nuclear weapons by India and Pakistan. The two countries revealed their covert possession of nuclear arsenals by testing their weapons in May 1998. Primarily, India and Pakistan developed nuclear weapons with the aims of countering each other but Indian nuclear ambition has a little more to do with China. India is significantly larger than Pakistan in physical size, Gross Domestic Product (GDP), and in conventional military capability. Owing to the imbalance of power between the two countries, it would be difficult for Pakistan to compete with India successfully. Therefore, Pakistan, especially the weaker state at first opted for borrowing external powers to balance its stronger neighbour.

Pakistan joined the U.S.-backed SEATO (Southeast Asia Treaty Organization) and CENTO (Central Treaty Organization) pacts in early 1950s and moved closer to the United States and China. During the 1950s and early 1960s, Pakistan received massive amounts of armsand economic aid from the United States. However, Pakistan's external balancing could not properly improve its capacity and security as it expected. Hence Pakistan looked for nuclear capability as the only way of equalizing against a much more powerful rival India (Hilali, 2002). Meanwhile, the humiliating loss of East Pakistan in the third Indo-Pak war in 1971 and the Indian peaceful nuclear explosion in 1974 forced Pakistan to accelerate its nuclear program (Jones et al., 1998). In the same way, the defeat of Sino-India war in 1962 and the Chinese nuclear test in 1964 became a major motivating factor for India to conduct an underground nuclear test in 1974. Furthermore, the transfer of nuclear and missile technologies from China to Pakistan facilitated India's quest for nuclear arms. In fact, India first sought the security guarantee from the nuclear powers against external nuclear threat. But the answer was ambivalent and thus these conditions necessitated the development of nuclear weapons to counter China and Pakistan.

\section{Method}

This article is about territorial dispute between India and Pakistan over the territory of Kashmir. This qualitative research was done through analysis of printed and written documents in the form of published academic works, press statements, speeches and joint communiqué from both India and Pakistan sources.

\section{Results and Discussion}

\subsection{Hindu-Muslim Antagonism}

There is a wide-spread perception that Indo-Pakistan hostility rooted in the long period of Muslim rule over India (Dixit, 2002). The very first piece of Hindu-Muslim antagonism was said to be placed in their minds when General Muhammad Bin Qasim sent by the Umayyad dynasty conquered the Indus Delta region in Sindh (now in Pakistan) and established Indo-Muslim state. General Muhammad Bin Qasim raised the banner of Islam in Sindh in 712 A.D. and tens of thousands of Hindus and Buddhists suffered under his oppression (Raja, 2010). In the mean time, Sindh developed into an Islamic outpost where Arabs set up trade linkages with the Middle East and were later joined by the sufis (teachers) - however Arab influence was barely felt in the rest of South Asia (Heitzman \& Worden, 1996).

By the end of the tenth century, Mahmud of Ghazni, leader of the Turkic tribe, launched seventeen aggressive operations into Northern India, occupying Punjab as his eastern province. Similarly, in the thirteenth century, Shams-ud-Din Iletmish established a Turkic kingdom in Delhi and the Delhi Sultanate extended its influence east to Bengal and south to the Deccan. During Khalji Dynasty under Ala-ud-Din (1296-1315), he succeeded in bringing most of South India under its control for a period of time (Heitzman \& Worden, 1996). In the early sixteenth century, the Mughals occupied India under the leadership of Zahir-ud-Din Babur. When Babur passed away, his son Humayun took over the reign. But due to the untimely death of Humayun, his thirteen-year-old son, Jalal-ud-Din Akbar succeeded him and reigned from 1556 to 1605. Jalal-ud-Din Akbar continued to conquer, annex, and consolidate a far-flung territory bounded by Kabul in the northwest, Kashmir in the north, Bengal in the east, and beyond the Narmada River in the south. Mughal rules under Jahangir (1605-27) and Shah Jahan (1628-58) was significant for political stability, rapid economic activity, beautiful paintings, and monumental buildings (Heitzman \& Worden, 1996).

The last dynasty of the Mughals was Aurangzeb who seized the throne by murdering all his brothers and imprisoning his own father. There was a strong believe that the Hindu-Muslim co-existence achieved to certain 
extents by Indian civil society was fragmented by the extremist Islamic orthodoxy of Aurangzeb's rule from 1658 to 1707 (Dixit, 2002). During his fifty-year rule, Aurangzeb engaged in a series of protracted wars. The increasing association of his government with Islam further drove a wedge between the ruler and his Hindu subjects. Moreover, Aurangzeb withheld building of new temples; destroyed a number of them; banned music at court; abolished ceremonies; and persecuted the Sikhs in Punjab. Aurangzeb's harsh treatment over Hindus and the reversal of the liberal religious policies of his predecessors, particularly Akbar, were regarded as principal reasons for the disintegration of his empire (Lal, 2011). Therefore, there is a strong perception that Muslim assertiveness and Hindu resentment dating from the time of Aurangzeb aggravated the existing Hindu-Muslim antagonism.

Although the Muslims ruled India for over a thousand year until the advancement of the European colonial power, cultural and religious values and sentiments of the Hindus were safeguarded. Benevolence rule by certain Muslim rulers and their benefaction for high caste Hindus contributed to the failure to assimilate Hinduism into fold of Islam. In reality, Hindus had never reconciled to any form of integration with Muslim culture. There was deep-rooted resentment behind the obvious public affability. Muslims were often looked at as tainted and polluted, and treated as invaders. While Hinduism unwillingly acquiesced to Muslim rule, it continually endeavoured to weaken the Islamic society by corroding it from inside (Raja, 2010).

There is also another school of thought that the British rule of India from eighteenth century to independence intensified the hostility between Hindu and Muslim (Dixit, 2002). During the colonial period, the British took political power from the Muslim rulers in different part of India. In doing so, Hindus became natural allies of the British and both went all out to destroy social, educational, cultural and religious heritage of Muslims (Raja, 2010). When the famous mutiny took place and the participants were severely punished in 1857, the treatment of Muslim mutineers which was more severe than their Hindu compatriots produced antipathy not only toward the British but also toward the Hindus (Korbel, 1954). In the early period of British rule, Muslims were neglected and deliberately subjected to discriminatory treatment whereas Hindus were favoured with opportunities to participate in the lower levels of administration. More-over, Hindus also became secondary partners to the British economic and technological activities in India (Smith, 1994). This all facilitated Hindus to be the more prosperous and progressive partners of the power structure of British India until the first decade of the twentieth century. From being the rulers of India, the Muslim community became a comparatively backward and politically powerless segment (Dixit, 2002). In the meantime, the British practicing the policy of divide and rule made use of the ongoing antagonism between Hindus and Muslims for their own benefits.

The freedom movement that was to result in India's partition had its tangible beginning when the Indian National Congress was formed in 1885. Later a split took place when few Muslim delegates in the Indian National Congress left and formed the alternative Muslim League in 1906 (Nosotro, 2010). However, it is interesting to observe that despite the British policy of divide and rule and the formation of separate Muslim League, there was no significant Hindu-Muslim discord for nearly the first three decades of the twentieth country (Dixit, 2002). Though separate political and social movements, they generally cooperated with each other in the national movement and worked together for the vision of independence. Leaders of the All-India National Congress and All-India Muslim League participated in each other's meeting and movement till 1928.

However, the harmony between Hindus and Muslims gradually grew apart and mutual suspicions germinated in the following years. When the Congress drafted a blueprint in 1928 for a constitution of India with Dominion status, the Muslim leaders accused the Congress of having completely ignored the special position of the Muslim population (Korbel, 1954). Despite Mahatma Gandhi being a firm believer in secularism and committed to providing equal respect to all religions, his emergence as the foremost leader of the Indian National Congress spawned concern among Muslims (Dixit, 2002). In the meantime, Mohammed Ali Jinnah, the creator of Pakistan had aspirations to take the national leadership role of Hindus and Muslims. But Mahatma Gandhi, Motilal Nehru, Jawaharlal Nehru and Pandit Madan Mohan Malaviya had already achieved an important role in the Indian National Congress and emerged as mass leaders. Therefore, Jinnah's attraction to the congress diminished from the late 1920s resulting in his moving towards the leadership of the Muslim community (Dixit, 2002). Moreover, Mohammed Ali Jinnah had no patience with Nehru's philosophy of the oneness of the Indian nation and what was to Nehru "unity in diversity" was to Jinnah "conflicting ideas" (Korbel, 1954).

The fracture between the political leadership of Hindus and Muslim was further aggravated by the announcement of the Communal Award by the British in 1932. The award provided for a representational and voting scheme for separate electorates, weighted representation and reserved seats for different communities in the provincial legislatures and the federal legislature of the government of India. Despite their claim to represent the Muslim masses, the Muslim League performed very poorly against the Indian National Congress in the elections. The 
Congress swept the polls in almost all of India including in the Muslim majority areas. As a consequence, the Muslim League felt that the Indian National Congress was going to weaken the Muslim League and its claims to represent the Muslim community in India. Moreover, Muslim League accused the Congress of planning to refuse Muslim rights in future Indian government and insisted the formation of separate nations based on the fact that both must be equally accommodated in the subcontinent with an autonomous homeland for Indian Muslims (Dixit, 2002). As a result, the "two nation theory" was born under the leadership of Jinnah. This theory and their aspiration were clearly reflected in the Pakistan Resolution passed by the Muslim League in 1940 at the Lahore session of the League. In fact, the last fifteen years prior to independence and partition were clearly stained by a growing antagonism between the two prominent political movements - the All-India National Congress and the All-India Muslim League (Korbel, 1954).

During the Second World War, the British government showed its general support to the aspirations mentioned in the Pakistan Resolution in order to achieve Muslim support for the war effort and for increasing recruitment of Muslims in the army. As a result, the Muslim League emerged as a credible political force and succeeded in almost gaining parity with the Congress in the interim government formed in New Delhi. In the mean time, the British Government sent a Cabinet Mission in 1946 to discuss plans for political reforms and self-government in India. The plan complied with a number of demands of the Muslim League but denied partition and the formation of separate Muslim state. The Cabinet Mission also rejected the demand of the Congress for direct non-communal representation in the central legislature and the creation of a strong central government. Therefore, Indian National Congress refused the plan and asked more discussions for an alternate plan.

However, the Indian National Congress and the Muslim League themselves could not agree on the composition of the government and as such the plan finally collapsed. After recognizing the impossibility of bringing the Indian National Congress and the Muslim League together to create a common government, Lord Mountbatten, the viceroy of India came to the conclusion that partition was the only possible solution (Korbel, 1954). Given that volatile situation, Mountbatten hurried the process of partition and advanced the date for the British departure by one year from June 1948 to 15 August 1947 (Dixit, 2002).

\subsection{State of Jammu and Kashmir}

The history of Kashmir before 1947 can be generally categorized into four periods - Hindu and Buddhist rule; Muslim rule; Sikh rule and Dogra rule (Rahman, 1996). However it is more interesting from the 1820 onwards when the Sikh rulers overpowered the Afghans. During the time of Sikhs rule, everything was going on smoothly till the 1845 when the first Anglo-Sikh war broke out and the two treaties were concluded between Sikhs and British (Dixit, 2002). The first treaty, signed in Lahore on 9 March 1846 promised the British an indemnity of 10 millions rupees for the state of Kashmir and the hill country between the Beas and Indus Rivers including the province of Hazara while the second treaty, signed in Amritsar on 15 March 1846 gave all mountainous country and its dependencies situated east of the Indus and west of Ravi River including Chamba to the British (Dixit, 2002).

However, the Sikhs could not pay the indemnity and as such Gulab Singh gave the British a discount sum of 7.5 million rupees in return for the possession of Jammu, Kashmir, Ladakh, and Baltistan. Therefore, the Hindu monarchy in Kashmir had been established in 1846. The Maharaja was given this bargain kingdom for two reasons. First, he had assisted the British in making an orderly retreat from the unfortunate British Afghan expedition. Second, Gulab Singh had signaled that he would defend British interests in the Punjab following the conclusion of the Anglo-Sikh war and the defeat of the Lahore kingdom (Ganguly, 1997).However, Gulib Singh did not get the possession of Kashmir without difficulty. Sheikh Islamuddin, governor of Kashmir fought Dogra troop with the help of Bambas from Jhelum Valley. But the British dispatched Brigadier Wheeler and his troops from Jullundar, together with 17,000 men from Sikh army. Finally Sheikh Islamuddin conceded and allowed Gulab Singh to enter Srinagar on 9 November 1846 (Rahman, 1996).

During the reign of Maharaja Gulab Singh, Kashmir was reasonably flexible and predominantly Muslim subjects were treated equally with their Hindu compatriots. However, all of his successors were biased, ruthless and authoritarian. Following the period of Maharaja Gulab Singh, Kashmiri Brahmins, known as pandits and the Dogras controlled most of the agricultural land; and the majority of the Muslim populations who worked on these lands were subject to the pandits and the Dogras (Ganguly, 1997). Similarly, the last Hindu monarch of Kashmir, Maharaja Hari Singh did very little to alleviate the grievance of his Muslim population. Despite Muslim represented 53 per cent of the population in southern Jammu Province and 93 per cent in the more populous northern Kashmir Province, they were a community without wealth or influence (Copland, 1981). Similarly, Hindus and Sikhs held 78 per cent of gazette appointments in the government while the Muslim stood 
only 22 per cent.

In 1931, some events increased the flame of opposition to the ruler. With the consent of the Maharaja, a mosque in Jammu Province was demolished by the Hindus while Muslims were prevented from offering their prayers (Rahman, 1996). All these and some other incidents intensified hatred of the Maharaja and led Muslims to launch an independence movement against Maharaja under the leadership of Kashmiri Muslim, Sheikh Mohammad Abdullah. He led a major revolt and therefore he was imprisoned for a time (Bose, 1997). Later he founded a political party called "Jammu and Kashmir Muslim Conference" in October 1932. Abdullah later realized that the freedom movement should be conducted on secular, democratic and progressive ways and as such Nehru and Prem Nath Bazaz became his mentors in his quest for secularization. As a result, Abdullah formally replaced the name of the Muslim Conference with the "Jammu and Kashmir National Conference" in 1939 so that it could become a focus for all the peoples of Kashmir including the Hindus. But Abdullah received strong opposition to his secularization process.

In 1941, Chaudhri Ghulam Abbas disassociated himself from Abdullah and joined Mirwaiz to restore the Muslim Conference. Generally, the Jammu and Kashmir Muslim Conference allied with the Muslim League led by Mohammad Ali Jinnah represented the interests of Muslims in Kashmir where as the Jammu and Kashmir National Conference represented only the Congress and Hindu interest (Rahman, 1996). However, the Jammu and Kashmir National Conference strengthened its position in the war periods as it welcomed Muslims, Sikhs and Hindus. But its secular appeal was based more on a common hatred of the Maharaja's autocratic Government than on any sense of mutual brotherhood (Dawson, 1994).

In 1946, Abdullah launched "Quit Kashmir" movement similar to Gandhi's "Quit India" (Bose, 1997). He also challenged that the British sale of Kashmir to Gulab Singh was an invalid act and demanded that the Dogra dynasty leave Kashmir immediately. As a consequence, he was sentenced to nine years imprisonment. However, his incarceration affected little to the tempo of the movement as Jawaharlal Nehru and Mohanas Gandhi rallied to Sheikh Abdullah's cause (Ganguly, 1997).In January 1947, the Maharaja held elections for the legislative assembly where the Muslim Conference swept a majority of the seats. In July 1947, the Jammu and Kashmir Muslim Conference passed a resolution that the state should join Pakistan (Rahman, 1996).

\subsection{Partition of Indian Subcontinent}

In February 1947, the government of Great Britain expressed its unambiguous intention to take necessary steps to carry out the transfer of power to responsible Indian hands by a date not later than June 1948. Accordingly, on $20^{\text {th }}$ February 1947, Prime Minister Clement Attlee announced that "if an agreed constitution by a fully representative assembly was not worked out by June 1948, the British government would have to consider to whom the power should be handed over on the due date, whether as a whole to some form of central government of British India, or in some areas to the existing provincial governments, or in such other way as may seem most reasonable and in the best interests of the Indian people" (Rahman, 1996). In order to carry out the transfer of power smoothly, Lord Mountbatten was appointed as Governor General and was assigned the task of facilitating the peaceful transfer of power to the new authorities - which is either the government of a united India or the two separate governments of India and Pakistan (Korbel, 1954). However, he finally favoured the path of two separate governments, after realizing the difficulty in bringing the Indian National Congress and the Muslim League together (Ganguly, 1997).

Based on Mountbatten's suggestion, the British government announced a plan for the partition of India on $3^{\text {rd }}$ June 1947. Despite the Congress leaders had passionately opposed the partition and the demand for the creation of Pakistan, they ultimately voted to accept the partition resolution on $15^{\text {th }}$ June 1947 . Six weeks later, on $18^{\text {th }}$ July, "the Indian Independence Act" was passed in which it was stating that India and Pakistan were to become independent countries on 15 August 1947; and the partition was to take place according to communal allegiance - the predominantly Hindu provinces were to form the Union of India and the predominantly Muslim provinces were to form Pakistan (Korbel, 1954). According to the Indian Independent Act, the Independence Day would be about ten months ahead of the scheduled date set by British Prime Minister Attlee in his first statement about the transfer of power.

There were 565 princely states representing 33 per cent of British India. Under the terms of the Indian Independence Act, none of the princely states would be allowed to declare independence (Ganguly, 1997). Mountbatten also made it clear that the doctrine of paramountcy would lapse after British withdrawal. In this regard, he was successful in his effort to persuade the princes into making timely decision for accessions and thus 562 of the 565 princely states except Hyderabad, Junagadh and Kashmir had acceded to India prior to the transfer of power (Wirsing, 1994). Finally India and Pakistan emerged as separate independent states on 15 and 
14 August 1947 respectively. However, the expectation of the Muslim leaders that Muslim-majority provinces and princely states especially the Princely state of Jammu and Kashmir would automatically join Pakistan was not completely fulfilled and as such this situation bred long-lasting antagonism, suspicion, hostility, wars, military built-up and nuclear arm races between the two countries in the following years.

\subsection{Accession of Kashmir to India}

In fact, the accession of Kashmir was the most painful and it brought the most troublesome consequence in Indo-Pakistan relations. When it came to the issue of accession, the theory of geographic contiguity could not perfectly be applied in the case of Jammu and Kashmir as it was contiguous to both India and Pakistan. Similarly, the basic principle that the ruler should decide while taking into account the aspiration of his people was also confused by the fact that the ruler of Jammu and Kashmir was a Hindu who might well incline to the Hindu state of India while the majority of his subjects were Muslim who might be expected to prefer joining the Muslim state of Pakistan. Besides, all these sensitive conditions were further confused by the fact that Sheik Mohammed Abdullah, the foremost Muslim leader in the state and organizer of Jammu and Kashmir National Conference, was in favour of accession to India (Dawson, 1994). To make the matter worse, the ruler of Kashmir, Maharaja Hari Singh himself covertly harboured visions of independence ignoring Mountbatten's explicit injunction (Ganguly, 1997).

Therefore, despite receiving dual approaches to join their state form both Indian and Pakistani representatives, Maharaja Hari Singh was not responsive to the National Conference or Muslim League as he was inclined to declare Kashmir an independent state with himself as the monarch. While Jammu and Kashmir Muslim Conference wanted Kashmir to become part of Pakistan, National Conference led by Sheikh Abdullah was opposed to the idea of Kashmir becoming part of Pakistan. In the mean time, Nehru and Sardar Patel informed Jinnah and Liaqat Ali Khan that the accession of the princely states to any dominion should not be based on the decision made by their rulers arguing that it is the people of the princely states who should decide their own political status. However, Jinnah hoping Nizam of Hyderabad and Maharaja of Kashmir would join Pakistan responded that the princes were the only one who had the political and legal legitimacy to decide the future of the states which they ruled. Therefore, it was Jinnah and the top leadership of the Muslim League who refused to accept arguments about territorial arrangements on the basis of democratic dispensation or the wish of the people (Dixit, 2002).

Just three days before the announcement of Independence, Maharaja Hari Singh offered a Standstill Agreement to India and Pakistan saying that he would need some time before reaching a final decision on the status of Jammu and Kashmir. Pakistan signed such an agreement but negotiations with India were never completed (Dawson, 1994). By doing so, he temporized on the issue of accession beyond the granting of independence to India and Pakistan in August 1947. However, internal disturbances in Jammu and Kashmir were unfortunately intensified due to the imprisonment of the leaders of both the Muslim Conference and National Conference. This atmosphere was further aggravated by the Hindu-Muslim riots in Jammu as well as violence against the rural Muslim peasantry in the Valley followed by a tribal rebellion near Poonch in the first week of October 1947.

On $24^{\text {th }}$ October 1947, the Poonch rebels formally declared their independence from the Maharaja and formed the government of Azad (free) Kashmir. The new government of Pakistan took full advantage of this situation by sending its troops disguised as local tribesmen to join the rebel. Retired Major General Akbar Khan of the Pakistan Army confirmed that as early as late August and September 1947, Pakistani political and military leaders meeting in Murree had discussed the measures and the time-frame for occupying Jammu and Kashmir and making it part of Pakistan (Dixit, 2002). On the morning of $22^{\text {nd }}$ October 1947, the invading column composed of Pathans tribesmen from North West Frontier Province of Pakistan and Pakistan army personnel in mufti, captured the town of Muzaffarabad and Uri (Ganguly, 1997). The invasion reached full operational level from $27^{\text {th }}$ October 1947 onwards. The raiders further occupied Poonch, Baramulla and moved towards Srinagar, capital of Jammu and Kashmir.

Caught in panic, Maharaja Hari Singh sought assistance form the neighbouring princely state of Patiala. Patiala provided their infantry battalion but it was inadequate to drive back the raiders. Therefore, Maharaja facing with imminent fall of Srinagar appealed to Indian Government for military assistance. Mountbatten received the request on $24^{\text {th }}$ October and called a meeting of the Indian Defence Committee on the next day (Ganguly, 1997). In consultation with Prime Minister Nehru and Home Minister Sardar Patel, Mountbatten insisted that the Instrument of Accession should precede the dispatch of troops (Dawson, 1994). He argued that it would be improper to send troops into an independent state since Pakistan might then do exactly the same (Campbell-Johnson, 1951). On the same day (October 25), V.P. Menon (constitutional advisor to Lord 
Mountbatten) was sent to Srinagar to inform Maharaja Hari Singh of the necessity to sign the Instrument of Accession first in order to get Indian military assistance.

Under this circumstance, the Maharaja, supported by Sheik Abdullah, leader of Jammu and Kashmir National Conference signed the Instrument of Accession on $26^{\text {th }}$ October 1947 (Ganguly, 1994). In his covering letter, Maharaja Hari Singh promised to set up an interim Government and to ask Sheik Abdullah to carry out responsibilities in the emergency in conjunction with the Prime Minister (Birdwood, 1956). V.P. Menon returned to New Delhi on $26^{\text {th }}$ October with the signed instrument and the Maharaja's request for Indian troops. Lord Mountbatten accepted the Instrument of Accession on $27^{\text {th }}$ October 1947 but included the clause in his covering letter that "... in consistence with their policy that in the case of any State, where the issue of accession has been the subject of dispute, the question of accession should be decided in accordance with the wishes of the people of the State, it is my Government's wishes that as soon as law and order have been restored in Kashmir and her soil cleared of the invader, the question of the States' accession should be settled by a reference to the people ..." (Birdwood, 1956).

Shortly after accepting the instrument, India sent its paratroopers to Srinagar. Even though the swift dispatch of the Indian troops to Srinagar, the invaders managed to occupy about one-third of the state (Ganguly, 1997). Full-scale fighting between Indian and Pakistani regular forces broke out in November 1947. The fighting continued in a desultory manner but neither side made significant territorial gains throughout the month of December (Ganguly, 1997). With regard to the chronicle of the accession of Jammu and Kashmir to India, there has been assumption that it is merely a fabrication to legitimize the Indian action. Alastair Lamb was the first who pointed out that the instrument of accession was postdated as the Indian army was already in Kashmir (Rahman, 1996).

In the mean time, Lord Mountbatten met Jinnah in Lahore on $1^{\text {st }}$ November 1947 as the Prime Ministers of both India and Pakistan were too ill to meet each other (Campbell-Johnson, 1951). At the meeting, Mountbatten proposed UN-sponsored plebiscite, which Jinnah rejected and put forward a plan by which the two Governors-General would issue a joint declaration calling for a ceasefire (Korbel, 1954) and if the tribesmen did not obey, the two armies would take collective action against them and the Governors-General would take control; enforce demilitarization, and then organize a plebiscite (Birdwood, 1956).

However, Pakistani proposal was rejected by Indian government and Nehru responded that "we are prepared when peace and law and order have been established to have a referendum in Kashmir under some such international auspices as that of the UN" (Birdwood, 1956). India also made counterproposal stating that Pakistan must take actions to compel the raiders to withdraw from Kashmir. India would than reciprocate by withdrawing their troops from Kashmir, following which both governments will make a joint request to the United Nations to administer the plebiscite in Kashmir with the least possible delay (Rahman, 1996). When the two sides held talks in December 1947, the idea of inviting a UN Commission to make recommendations to ensure a fair plebiscite was discussed. But the talks failed when Pakistan disclosed its inability to force the invaders to leave and India refused to withdraw her troops until Pakistan did (Menon, 1956). Mountbatten then suggested that the UN be called in unilaterally by India as he feared that if mutually acceptable solution could not be achieved, the fighting might transform into open war between the two dominions. Therefore, India referred the issue to the UN on $31^{\text {st }}$ December 1947 (Menon, 1956).

On the very same day, Pakistan also sent a response to Indian reference. But it was uncompromisingly negative for India and as such India followed up its former reference by formally appealing to the Security Council on $1^{\text {st }}$ January 1948 (Dixit, 2002). In this episode, it is quite interesting to learn that just before India decided to refer the matter to the UN, there were strong suggestions from India's military commanders conducting the operations in Jammu and Kashmir in 1947 and in 1948 that they needed only a few weeks more to push back all Pakistani personnel and troops out of Jammu and Kashmir and that India need not go to the UN (Dixit, 2002).

\subsection{The U.N. Intervention and Demarcation}

In its direct appeal to the UN Security Council (UNSC) on $1^{\text {st }}$ January 1948, India stated that "there now exists a situation whose continuance was likely to endanger the maintenance of international peace and security owing to the aid which infiltrators, consisting of nationals of Pakistan and of tribesmen from the territory immediately adjoining Pakistan on the northwest, under directions from Pakistan for operations against Kashmir, a state which has acceded to the Dominion of India and is part of India. The Government of India requests the UNSC to call upon Pakistan to put an end immediately to the giving of such assistance which is an act of aggression against India. If Pakistan does not do so, the Government of India may be compelled in self-defence to enter Pakistani territory in order to take military action against infiltrators. The matter is therefore one of extreme 
urgency and calls for immediate action" (Dixit, 2002).

On $15^{\text {th }}$ January 1948, Pakistan responded to the Indian reference to the UNSC in the name of "Pakistan's Complaint against India" denying its involvement in assisting the invaders and accusing India of genocide of Muslims in Jammu and Kashmir and stating that India had acquired Jammu and Kashmir by fraud and violence; and taken over Junagadh and Hyderabad through unfair means (Dixit, 2002). In fact, Pakistan cleverly managed to make the matter portrayed as the India-Pakistan case before the UNSC rather than Kashmir dispute which effective broadened the issue in the eyes of the world (Dawson, 1994). Therefore, India soon felt that the UNSC was more interested in deciding the validity of India's action in Kashmir and examining the Pakistan's charges against her, than in considering her complaint against Pakistan's aggression, and putting an end to the fighting in Kashmir (Dawson, 1994).

As a primary step, the Security Council passed resolutions on $17^{\text {th }}$ and $20^{\text {th }}$ January 1948 calling both countries to refrain from using forces and to seek a peaceful solution as to whether Kashmir should belong to India or Pakistan. Moreover, the resolutions made a provision for a three-member United Nations Commission for India and Pakistan (eventually composed of five members) to go to Kashmir as quickly as possible. However, the Security Council spent four months debating the issue before the Commission was finally established.The Security Council adopted another resolution 726 of $21^{\text {st }}$ April 1948 which mentioned the formation of the United Nations Commission on India and Pakistan (UNCIP) as well as the condition of plebiscite in detail (Wirsing, 1994).Moreover, the resolution recommended that Pakistan should secure the withdrawal of tribesmen and Pakistan nationals, and that India should progressively withdraw its forces to the minimum strength required for the maintenance of law and order. The resolution also suggested that a coalition cabinet be formed in Kashmir, representing all political groups and that Plebiscite Administrator be nominated to ensure free and impartial plebiscite.

The members of the UNCIP arrived at the subcontinent on $7^{\text {th }}$ July 1948 and held discussions with both parties. In those meetings, they found out that India wanted the fighting to stop before anything was done for the plebiscite while Pakistan argued that the fighting would automatically end if the plebiscite arrangements were agreed (Dawson, 1994). On $13^{\text {th }}$ August 1948, the UNCIP passed its first resolution 995. According to this resolution, both parties were to agree upon the issuing of a ceasefire order within four days of their acceptance of the resolution; the Commission would appoint Military Observers to supervise the ceasefire; troops withdrawals and the territorial evacuation were to be administered by the local authorities under the observation of the Commission; India would maintain a minimum force to assist local authorities in the observance of law and order; and both parties were asked to reaffirm their agreement that the future of Kashmir would be determined in accordance with the will of the people (United Nations Commission on India and Pakistan [UNCIP], 1948).

Following a series of detailed discussions, both parties accepted the resolution with some objections and proposals. The Commission then left the Subcontinent on $21^{\text {st }}$ September 1948 to draft new proposals to supplement its former resolution. After modification, the revised proposals were presented to both parties on $11^{\text {th }}$ December 1948 followed by detailed discussions. In its revision, the Commission proposed that the question of the accession of the state of Jammu and Kashmir to India or Pakistan be decided through the democratic method of a free and impartial plebiscite (Korbel, 1954). After accepting the Commission's revised proposals by both parties, the Indian Commander in Chief then duly contacted his Pakistan counterpart suggesting a ceasefire. Finally the ceasefire came into effect on $1^{\text {st }}$ January 1949 exactly a year after India brought the issue to the UN. The Commission later reaffirmed its revised proposal in a formal resolution 1196 of $5^{\text {th }}$ January 1949.

Following the acceptance of its modified Resolution by India and Pakistan, the UN Commission established a "Truce Sub-Committee" to find a basis of agreement between the two governments with the assistance of Military Advisor. Based on the recommendation of UNCIP, the Secretary-General then appointed General Maurice Delvoie as the new Military Adviser to support the Commission on military aspects and provided a group of military observers to assist him. The first team of unarmed military observers, UN Monitoring Group for India and Pakistan (UNMGIP) which eventually formed the nucleus of the United Nations Military Observer Group in India and Pakistan (UNMOGIP), arrived in the mission area in January 1949 to supervise the ceasefire between India and Pakistan.

Later on $2^{\text {nd }}$ July 1949, the UNCIP asked India and Pakistan to send their military representatives to Karachi to discuss the demarcation of a Ceasefire Line. Accordingly, the Joint military meetings were held in Karachi from $18^{\text {th }}$ to $27^{\text {th }}$ July 1949 and the historic agreement officially called "The Agreement between the Military Representatives of India and Pakistan regarding the Establishment of a Ceasefire Line in the State of Jammu and Kashmir" commonly known as "The Karachi Agreement" or "The Ceasefire Agreement" was successfully 
signed by the heads of both delegations and by the Chairman of the Truce Subcommittee and the Military Advisor.

The Ceasefire Line, more than 500 mile long, was separated into eight sectors covering the areas of Manawar, Kotli, Punch, Uri, Tithwal, Keran, Gurias and Kargil (Dawson, 1994). The military observer in charge of each sector called meeting of opposing commanders and surveyed with them the Line on the ground making a written description of the natural boundaries and establishing signs such as marks on trees or stone cairns. In doing so, the demarcation of a Ceasefire Line on the ground was completed on $1^{\text {st }}$ November 1949. This Ceasefire Line which was later renamed as Line of Control (LoC) in 1971 subsequently became the de facto border between India and Pakistan which remains till today. According to the Line of Control, somewhat more than a third of Jammu and Kashmir came under the control of Pakistan and is now more commonly known as Azad Kashmir in Pakistan and Pakistani Occupied Kashmir by India while the part remaining in India is referred to by Pakistan as Indian Occupied Kashmir (Widmalm, 2002).

On $14^{\text {th }}$ March 1950 , the Security Council passed Resolution 80 by which it appointed United Nations Representative in India and Pakistan (UNRIP). The resolution also provided for the termination of the UNCIP which was wound up by $1^{\text {st }}$ July 1950 . Again on $30^{\text {th }}$ March 1951 , the Security Council, through its Resolution 91, decided that the UNMOGIP which main functions were to observe and report, investigate complaints of ceasefire violations and submit its finding to each party and to the Secretary-General shall continue to supervise the Ceasefire in the State (Dawson, 1994). In the mean time, India held elections in Kashmir in 1951 and formed a constituent assembly to further integrate the state. To publicly defence India's action, Nehru said in a press conference on 11 June that no country had any business interfering and that the Indian government would tolerate no nonsense about Kashmir. The election of an assembly was seen in Pakistan as a step toward consolidation of India's hold on the state (Rahman, 1996).

India and Pakistan continued to accuse each other over the possession of Kashmir and the conflict translated into a total war in 1965. In this regard, the UNSC passed resolution 211 of $20^{\text {th }}$ September 1965 and resolution 214 of $27^{\text {th }}$ September 1965 demanding ceasefire and withdrawal of its troops back to the positions held by them before 5 August 1965 (United Nations Security Council [UNSC], 1965). However, the conflict was settled by the intervention of Soviet Union resulted in signing Tashkent Declaration in 1966 in which both parties agreed to restore status quo ante and to resolve outstanding issue by negotiation. Due to the renewed hostilities between India and Pakistan in 1971, UNMOGIP was tasked to observe developments pertaining to the strict observance of the ceasefire of 17 December 1971 (United Nations Military Observer Group in India and Pakistan [UNMOGIP], 1971).

\section{Summary}

The Hindus and Muslims of the Indian subcontinent have different and uncompromising religious philosophies, social customs, scale of values, and ways of life. They neither intermarry nor intertwine and they belong to two different civilizations which are based mainly on conflicting ideas and conception (Korbel, 1954). In fact, Kashmir issue has been an expression of their century old hostility and antagonism. The issue was further influenced by a process in which India and Pakistan took Kashmir as a symbol of their respective national identities (Cohen, 2003). Pakistan refused the existence of a Muslim majority under Hindu rule and stuck to the two-nation theory while it is impossible for India to leave out such predominantly Muslim region in order to defend their secular nature. Kashmir issue is also a conflict over national identities, territory, and power position between the two countries. Therefore, without understanding the significance of antagonism between Hindus and Muslims, it would be difficult to understand the evolution of Indo-Pakistan relations and the acquisition of nuclear weapons.

During this period, a number of proposals for the settlement of the issue have been put forward which include acknowledging the current $\mathrm{LoC}$ as the international border between India and Pakistan; joint development of Jammu and Kashmir; revival of the UN resolutions for holding plebiscite; granting independence to Jammu and Kashmir; redefining the existing boundary with some territorial adjustment. However, none of them was completely acceptable to India and Pakistan. Therefore, for the time being, the status quo or keeping the Line of Control is the only viable solution to maintain the Indo-Pakistan relations. Kashmir is the core issue that continues to bedevil relations between India and Pakistan. It is also one of the oldest conflicts in the UN history. Despite a series of UN resolutions, the two countries have been unable to resolve the dispute. India also claimed that Pakistan was the original invader and the Pakistan's support for the Kashmir insurgency was its attempt to take over Kashmir by force. Pakistan, on the other hand, claimed that Kashmir's accession to India was illegal and undemocratic. Further, Pakistan argued that India's continued refusal to hold plebiscite on the question of 
accession denied right to self-determination of the Kashmiri people.

Despite UN and many foreign countries including United States showed their interests and suggestions to solve the Kashmir impasse, all of their efforts were in vain and their suggestions proved to be abortive because none of them was wholly acceptable to India and Pakistan. However, India and Pakistan have expressed their interests to solve the protracted issue in an amicable way and agreed to find a solution over the possession of Kashmir by means of holding bilateral negotiations.

\section{References}

Birdwood, L. (1956). Two nations and Kashmir. London, England: Robert Hale.

Bose, S. (1997). The challenge in Kashmir: Democracy, self-determination and a just peace. New Delhi, India: Sage Publications.

Campbell-Johnson, A. (1951). Mission with Mountbatten. London, England: Robert Hale.

Cohen, S. P. (2003). India, Pakistan and Kashmir. In S. Ganguly (Ed.), India as an emerging power. London, England: Frank Cass Publisher. http://dx.doi.org/10.4324/9780203009888.ch3

Copland, I. (1981). Islam and political mobilization in Kashmir, 1931-34. Pacific Affairs, 54(2), 233-234. http://dx.doi.org/10.2307/2757363

Dawson, P. (1994). The peacekeepers of Kashmir: the UN military observer group in India and Pakistan. London, England: C. Hurst \& Co. Publisher ltd.

Dixit, J. N. (2002). India-Pakistan in war and peace. New Delhi, India: Books Today. http://dx.doi.org/10.4324/9780203301104

Ganguly, S., \& Kapur, S. P. (2010). The sorcerer's apprentice: Islamist militancy in South Asia. The Washington Quarterly,33(1), 47-59. http://dx.doi.org/10.1080/01636600903418686

Ganguly, S. (1994). The origins of war in South Asia: Indo-Pakistani conflicts since 1947. San Francisco, CA: Westview Press.

Ganguly, S. (1997). The crisis in Kashmir: Portents of war, hopes of peace. London, England: Cambridge University Press.

Heitzman, J., \& Worden, R. L. (1996). India: a country study. Washington D.C.: The Division. Retrieved from http://lcweb2.loc.gov/cgi-bin/query/r?frd/cstdy:@field\%28DOCID+in0017\%29

Hilali, A. Z. (2002). Pakistan's nuclear deterrence: Political and strategic dimension. Retrieved from http://sam.gov.tr/wp-content/uploads/2012/01/A.Z.-Hilali.pdf

Jones, R. W., McDonough, M. G., Dalton, T. F., \& Koblentz, G. D. (1998). Tracking nuclear proliferation: A guide in maps and charts, 1998. Washington D.C.: The Brookings Institution Press.

Korbel, J. (1954). Danger in Kashmir. Foreign Affairs, 32(3), 482-490. http://dx.doi.org/10.2307/20031046

Lal, V. (2011). Aurangzeb: A political history. Retrieved from http://www.sscnet.ucla.edu/southasia/History/Mughals/Aurang.html

Menon, V. P. (1956). The story of the integration of the Indian states. London, England: Longmans Green \& Co.

Nosotro, R. (2010). Hindu-Muslim conflict and the partition of India (online). Hyperstory.net. Retrieved from http://www.hyperhistory.net/apwh/essays/cot/t3w30pakistanindia.htm

Rahman, M. (1996). Divided Kashmir: old problems, new opportunities for India, Pakistan, and the Kashmir people. London: Lynne Rienner.

Raja, A. A. (2010). Hindu-Muslim antagonism. Asian Tribune. Retrieved from http://www.asiantribune.com/news/2010/01/14/hindu-muslim-antagonism

Smith, C. (1994). India's ad hoc arsenal: Direction or drift in defence policy. Oxford, England: Oxford University Press.

Tremblay, R. C. (2009). Kashmir's secessionist movement resurfaces. Asian Survey, 49(6), 924-950. Retrieved from http://www.jstor.org/stable/10.1525/as.2009.49.6.924 http://dx.doi.org/10.1525/as.2009.49.6.924

United Nations Commission on India and Pakistan. (1948). Resolution adopted by the United Nations Commission for India and Pakistan on 13 August 1948. Retrieved from http://www.mtholyoke.edu/acad/intrel/uncom1.htm 
United Nations Military Observer Group in India and Pakistan. (1971). Observing the ceasefire in Jammu and Kashmir. Retrieved from http://www.un.org/en/peacekeeping/missions/unmogip/

United Nations Security Council. (1965). Resolution 211 (1965) of 20 September 1965, S/RES/211. Retrieved from http://www.unhcr.org/refworld/docid/3b00f28518.html

Widmalm, S. (2002). Kashmir in comparative perspective: Democracy and violent separatism in India. London, England: Routledge Curzon.

Wirsing, R. G. (1994). India, Pakistan and the Kashmir dispute on regional conflict and its resolution. London, England: Macmillan.

\section{Copyrights}

Copyright for this articleis retained by the author(s), with first publication rights granted to the journal.

This is an open-access article distributed under the terms and conditions of the CreativeCommons Attribution license (http://creativecommons.org/licenses/by/3.0/). 